\title{
Professional Depositors and Interest Rate Risks for Banks: Russian Case of Significant Fluctuation of Exchange Rate and Federal Fund Rate in 2014-15
}

\author{
Sergey Vl. Anureev \\ Doctor of Economic Science, Professor at Plekhanov Russian University of Economics, \\ Finance Faculty, Department of Banking and Department of Financial Management, \\ Visiting professor at Lomonosov Moscow State University, Economic Faculty, Department of International Economics \\ Email: Anureev@bk.ru
}

\author{
Doi:10.5901/mjss.2015.v6n4p107
}

\section{Abstract}

Facing significant changes in exchange rate $(35 \rightarrow 72 \rightarrow 49$ RUR per 1 USD) and interest rate $(8 \rightarrow 17 \rightarrow 12.5)$ over a half year and private banks bankruptcies in previous crises Russian middle class, who are experienced in savings and risk taking, create sophisticated methods of depositing money. In December 2014, some Russian big private banks pessimistically forecasted significant inflation, peoples' aversion from bank deposits and high interest rate over several years. Many professional depositors (experienced retail savers) forecasted more optimistically, expected the repetition of an economic cycle of 2008-11, when high inflation and interest rate lasted over a half year and then declined quickly to the pre-crisis level. In panic every professional depositor signed tens of deposit contracts with minimal required balances and "fixed" high interest rates for 2-3 years, which would make commercial banks to realize significant interest rate risks. The research shows that professional depositors share is $24 \%$ of total household deposits, plus $11 \%$ of deposits of ordinary savers contributed to long contracts during crisis-high interest rates. When financial stability comes and market interest rate falls, banks will have to pay high interest on this 1/3 deposits and get negative gross margin about minus $1.5 \%$. Banks have to follow the deposit contracts and can not decline the interest rate, when vast majority of credits have the option to decline the interest rate as market one falls. Avoiding this interest rate risk realization, the Central Bank of Russia (CBR) should impose lower interest rates ceiling on saving and flexi fixed deposits (CBR regulates only the maximum interest rates on classic deposits) and smooth the interest rate gap toward on demand deposits. Also CBR should use conditional commitments more active, tells to the market that interest rate will de kept high over a short period of time, and allow commercial banks to raise deposit interest rates over the same short time only.

Keywords: Deposit insurance. Moral hazard. Professional depositors. Interest rate risk. Financial crisis. Federal fund rate. Central Bank of Russia

\section{Problem Set: The Nature of Professional Depositors and their Actions during Significant Interest Rate Fluctuations}

A term "professional depositor" is pretty much like a "professional buyer" term. Professional buyers have a big variety of discount cards and coupons and they are acutely aware of goods in the sale. Mainly they buy goods at a discount sold by various shops in a small variety to draw customers to purchase a wider range of goods. In towns with high percentage of professional buyers, retailers get no profit as many customers buy only goods with discounts and stick to sales promotions. As professional buyers are a problem for retailers, professional depositors make use of mistakes of private banks and banking regulator.

The "professional depositor" term was first used in a bank industry in the early 2000s. After the system crisis of 1998 the vast majority of depositors preferred Sberbank (the largest state owned bank) and other state owned banks to private banks. Less than $1 / 5$ depositors consciously took risks of mid size private banks, because they were able to analyze banks' solvency, insider information and gossips, knew ways of emergency settling deposits assigning credits. In business Mass Media that term was first used in a series of interviews with A.A.Kozlov. In the early 2000s he was the senior vice-president of the Central Bank of Russia (CBR, cbr.ru) and was developing criteria for a deposit insurance system.

Establishment of the deposit insurance system in the middle of the 2000s stimulated significant growth of professional depositors. The State Deposit Insurance Agency (DIA) shall be obligated to compensate deposit sums up to 700 thousand rubles or 25 k.\$ (1,4 million starting from 2015) per person per bank when the bank license be revoked. So professional depositors consider their risk of depositing money in private banks as an obligation of the government agent, 
which, in fact, is alike a Sberbank risk.

Interest spread between relatively low Sberbank interest rates and risky private banks, where deposits are insured by the DIA, sometimes achieve up to 5-6 percentage points. Having such expensive funds "risky banks" keep high interest rate on credits, and take only borrowers with low creditability, which do not satisfy credit policy of state owned banks. As the result, risky banks have phony capital stocks and gaps in assets patched by sufficient cash inflow from adventuresome professional depositors.

Assumption of professional depositors is that the state pay for everything because it bears high social responsibility, has minimum government debt and non strict bank supervision. The main rule of the professional depositors is not to exceed the maximum DIA insurance coverage, so they split their deposits between relatives' accounts and several risky banks. In the worst scenario they don't get income in a month or two from the moment the bank was closed till receipt of refund from DIA. Such probable ad-hoc losses of $0.5-1 \%$ of a deposit are minor compared to additional $5-6 \%$ of professional depositors yield.

In business Mass Media, among professional bankers and employees of CBR there is a clear understanding of the phenomena of professional depositors and risky banks. Managers of the biggest banks frequently criticize bank supervision, assuming quite fairly that their high in-payments finance professional depositors' fiesta. In response to criticism from stable banks, bank supervision introduced maximum limitations of deposit interest rates and differentiation of DIA insurance payments. The unspoken viewpoint of the bank supervision is that toxic assets could appear in every bank, and a bank should have a chance to work that problem out.

Some statements regarding professional depositors by state officials and bankers should be quoted here. Thus, Nataly Burykina, chairman of the State Duma (Russian Parliament) Committee on Financial market, said: "We are conscious about the fact that many depositors in the Russian banking system make profitable business on deposit insurance, which is unacceptable." [rus 1]. Mr. Isaev U.A., head of DIA, highlights that "the system involves moral hazard: we see the same depositors getting compensation every time. They are professional depositors of bankrupt banks. They identify financial institutions with overrates and deposit their savings there aware that they are insured." [rus 2]

Fixers, as a subtype of professional depositors, play a more complex game with fluctuations of interest rates, more precisely - on their decline after crisis peaks. First time they appeared in 2008-9, after CBR and private banks raised interest rates significantly during the peak of crisis. Later on ruble exchange-rate reverted along with recovery of confidence in the banking system and economy, and interest rates fell. So, those who took a risk of ruble highly yield long-term deposits in the crisis peak doubled their savings over 2009-13, in comparison with tiny interest rate on dollar denominated deposits. Fixers became very numerous during the banc panic in December 2014 so that bank operators could hardly manage influx of fixers.

It should be recalled that during the stable 2011-2013s Sberbank reduced deposit rates to 5-7\% and big private banks to $8-10 \%$ at maximum. In the peak of speculative attack against ruble and deposit runoff into imported goods, CBR raised the federal fund rate up to $17 \%$, and big private banks raised their deposit rates up to $18-21 \%$. Expecting repetition of the scenario of the previous crisis and the recovery of 2008-11, fixers were bracing themselves for relatively quick reduction of interest rates after the end the attack. They also relied on verbal intervention of government officials and conventional wisdom, that high interest rate could damage economic activity and should be quickly declined to pre crisis level.

Forecasts of professional depositors, bankers and economic institutions were based on the following statistics for 2009-2011 [rus 3]:

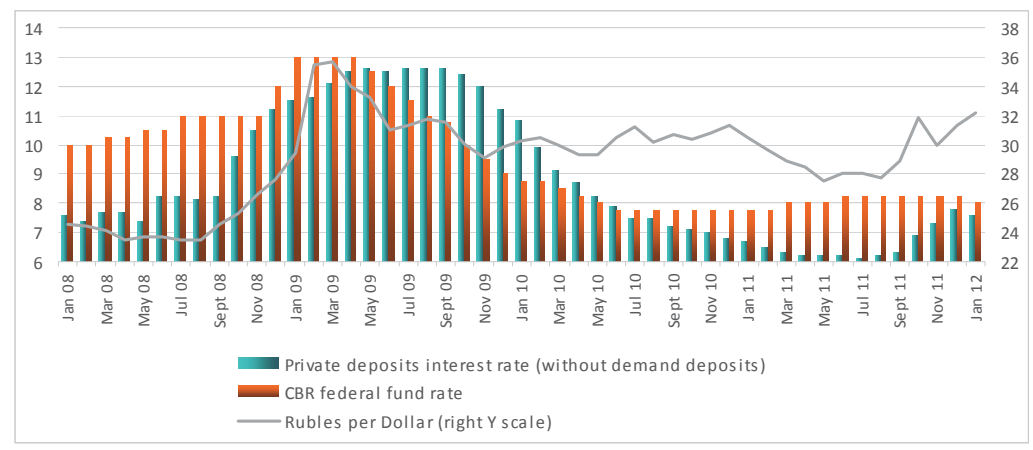


So what do fixers, a subtype of professional depositors, fix? Very often fixers can't withdraw their savings without loss of interest accrued during the weeks of extremely high deposit rates. Or, they do not ready to take high risk on all their savings during the peak of crisis, only when high yield deposits offered. But they have an opportunity to put savings in the deposits later, by depositing now a minimum required balance on saving deposits and flexi fixed deposits.

Having relatively small money (with the bulk of money on actual deposits), fixers sign a lot of new deposit contracts and put minimum required balances on the deposits. Then actual deposits will expire and the professional depositors will add released sums to new highly yield deposits, which contracts they signed during the crisis. Two or three months after the peak of crisis, banks start to reduce high interest rates, but fixers continue to benefit from signed deposit contracts with crisis high rates for years.

What fixers do is like a purchase of an interest rate derivative contract on the stock exchange speculating for reduction of interest rates. On purchase of an exchange-traded contract a security deposit should be paid - equivalent of a minimum balance of saving deposits. Reduction of actual interest rates will increase the price of derivative contract providing excessive profit to a speculator. If the interest rate forecast is wrong, a speculator loses the security deposit, but doesn't risk the main capital. Investing in derivatives require more special skills and generally more complicated compared to visit to a bank for deposits. On the other side a stock exchange handles a big number of contracts with many clients easier than bank staff work with crowds of fixers.

\section{Literature Review: Does Russian Phenomenon Happen Anywhere Also}

It is really hard to explain such a unique Russian phenomenon as "professional retail depositors" with a direct evidences or analogies from other countries. Tens of specific examples from other countries and research articles can be used as evidence, it is like putting a lot puzzle pieces into a picture. The first way of searching for the analogues is the moral hazard of bank deposit insurance, the second way is interest rate risk sharpened by financial crisis and following recovery, the third one is post Soviet Union countries with similar banking and academic landscape.

In modern history probably the most impressive interest rate realization is the sub prime mortgage crisis in the US in 2007-08, which drove world economy down to recession. The problems began when millions of American households did not correctly estimates the impact of interest rate changes in personal finances. When interest rates were low as the result of banks rebates and soft monetary policy, households' borrowing and purchasing of real estate drove American economy. But expiration of starting interest rate rebates and noticeable increase in federal fund rate damaged the solvency of millions of households. Interest rate risk realization, as the result of wrong assumptions and strategies of people and banks, was fundamental starting point of the financial crisis and global resection. The difference from Russian researched case is the bank product (deposit, not credit) and financial results of clever bank customers (who got extra profit, not losses). The key similarity is bank losses as the result of wrong forecasting of interest rate changes over an economic cycle and financial turbulence. So many articles and even books written about American sub prime mortgage crisis and it could be enough to briefly refer this case as bright example of interest rate realization in bank operations with households.

Among the key words from researched Russian cases, the most frequent are moral hazard and deposit insurance. So, researchers of deposit insurance in Canada, Gueyie1 and Laib (2003), pointed that "insured banks increased leverage and assets risks". Bartholdya et al., (2003) investigated "the moral hazard incentives generated by deposit insurance result in a greater probability of bank default". Anginera et al. (2014) wrote: "the reduction in the incentive of depositors to monitor banks leads to excessive risk-taking". They specially investigated the system-wide risks and pointed that "generous financial safety nets increase bank risk and systemic fragility in the years leading up to the global financial crisis".

There are no unique Russian features, when some bankers and depositors consciously take bigger risks and expect bailout from state agency (или state agencies или the state agency)- listed research patterns disclose conventional attitude towards moral hazard of deposit insurance. Coming back to the Russian case, all listed opinions are exactly true in general and for the case of professional depositors' behavior in particular. The research goal is not the repetition of obvious conventional points, but deep investigation of depositors' behavior, features of deposit contracts and regulatory frames, quantitative calculations of the phenomenon size and influence on interest margin.

Maechler1 and McDill (2006) researched the US practice of bank straggling for depositors by raised interest rates on uninsured deposits. The similarity of the US and Russian cases is high deposit prices to attract new depositors, but the difference is "who pays for the lunch". In the US the practice is effectively constrained by depositors' discipline and their high risk, because banks offer higher interest rates on uninsured deposits. The US approach of fair risk taking and market force constrain of risk taking is significantly contrasted with Russia, where professional depositors "eat biscuits" 
and the federal government "pays for these sweets".

Smitha and Egterenb (2005) combined moral hazard not with deposit insurance, but with crisis bank refinancing. They pointed that "if the central bank provides (liquidity) insurance (at zero premia), it may introduce a classical moral hazard problem that encourages risk taking by banks". Their point of view is far from Russian crisis reality, where the Central bank raises interest rates significantly and pumps expensive/big money to the economy instead of cheap/small one, but the similarity is moral hazard and bailout by the state. In both cases monetary policy makers distort bank business, increase long-term instability and magnitude of a future crisis.

Yanga et al., (2014) investigated the interest rate risk European countries realized during the 2007-09 crisis. The researchers pointed and quantified the following chain of events: "increased credit risk within the US financial system propagated to the European markets' liquidity risks", "the interest rate risk contagion is especially severe for some countries in the Euro regions with greater sovereign debt problems". In the Russian case the interest rate risk is also caused by external shocks in forms of oil prices fall and foreign borrowing restrictions, but without substantial sovereign debt problems and credit risk rise. Outstanding behavior of Russian retail depositors is caused by significant currency devaluation and high inflation expectations, which are not compensated by low (pre-crisis) interest rate.

Gimeno and Marqués (2012) investigated "the inflation expectations and the real interest rate by using the information contained in the yield curve". As the researchers did, Russian professional depositors quickly estimated the downward slopping yield curve in general and different curve slops in different banks under deposit insurance. In both cases the yield curve is a primary tool for inflation expectations and prediction of real interest rate, and by the curve prediction professional depositors make money from the imperfection of monetary regulation.

Hasana et al (2013) estimated the rational behavior of depositors in the Central European countries under the flow of news and rumors about banks financial distress. The puzzle fragment to the Russian reality, extracted from the Central European case, is how "depositors react rationally to sources of information other than financial statements" and moderate unexpected (unexpected for monetary policy makers) behavior patterns, do it so quickly and in large volume.

Schluetera et al (2015) investigated the "behavioralization' of bank balance sheets since deposit funding increasingly consists of non-maturing deposits with uncertain cash flows exposing". Russian banks deposit base is statistically long-term, but practically majority of professional depositors prefer flexi fixed and saving deposits, and early deposit withdrawal could be around $25-40 \%$, as the researchers pointed in their case. Russian depositors do not simply withdraw money as during classical bank runs, but quickly reflect changes in interest rate - Russian banks face quick, substantial and long-term increase in costs of their passives.

Zulkhibri (2012) estimated "the short- and long-run interest rate pass-through and analyzed the asymmetric behaviour of financial institutions under different monetary regimes" in Malaysia. The key idea of both Malaysian and Russian cases is quick market reflection of significant changes of federal fund rate, including deposit and lending rate, under monetary easing and monetary tightening. The difference between the cases is general or average market reflection in Malaysia and the behavior of professional depositors in Russia with their quick and significant influence on bank margin.

Wanga and Leeb (2009), as some of the previously referenced researchers did, "examined the interest rate passthrough mechanism between the money market rate and the retail interest rate" in the U.S. and nine Asian countries. The important feature of the research is a noticeably big number of countries investigated, compared to the narrow specific Russian case. The researchers found various patterns of the interest rate pass-through mechanism and volatility, but could not deeply and variously explain the countries results. In the Russian narrow specific case the mechanism is widely explained by the analysis of the previous crisis, historical macro data, depositors' role-models, features of deposit contracts, deposit insurance and monetary policy.

One of the articles about the Russian banking system is written by Chernykha and Coleb (2011): "the study examines how the introduction of deposit insurance affects depositors and banks". And the deposit insurance (risky deposits bailout by the state) is the key assumption for researching professional depositors. The authors sharpened many important cases about the Russian banking system, including rapid growth of privately owned banks, the system moral hazard and increased bank risk-taken. Compare the article by Chernykha's and Coleb's and the research, the article is based on marco evidences the most, and the research is based on wider facts and evidences, not only macro economic and bank regulation, as written before.

The second referenced article about the Russian banking system is written by Fungáčová1 et al (2010). Unfortunately for our research, this article is about "bank competition in Russia by measuring the market power of Russian banks and its determinants in the period of 2001-2006 with the Lerner index". The article correctly pointed several features of the Russian banking system, such as market concentration and nonlinear influence of banks' size. The article is based on statistic evidences, completed/compiled? a year after the introduction of deposit insurance, before 
the system got noticeable results. Also, the article, as one of the previously referenced, is more about macro evidences, without behavioral, contractual and regulatory features.

The third important article about the Russian banking system points at financial literacy and financial crisis, and the article authors are Klappera et al (2013). The article is mainly about our research, where the depositors' behavior really depends on their knowledge and experience in banking and finance. Studying financial literacy and its influence on banks and economy in general, the article authors also point out household borrowing and negative income shock after financial crisis of 2008. The research is about other sides of a banking business (not household credits, but deposits), and mass repetition of successful depositors behavior during the recovery after the crisis of 2008.

The next referenced article intersected with the research is about "central bank transparency in the transmission mechanism of monetary policy through the interest rate channel", written by Papadamoua et al (2014). The obvious article result is "when the central bank's monetary policy is more transparent, the transmission mechanism of that monetary policy is more effective. And highly transparent central banks do not need to be aggressive in their policy rate actions." This obvious idea is really important for Russia and behavior of professional depositors, especially in the case of outstanding and emergency increase of the federal fund rate in December 2014, which triggered the raids of professional depositors and evaporation of bank interest margin.

Jonesa and Kulishb (2013) researched "announcements about the future path of the short-term rate and long-term nominal interest rates as operating instruments of monetary policy". The article topic is important for the Russian case, because the Bank of Russia has been only accumulating experience with unconventional monetary policy tools, and professional depositors realize higher yield based on the monetary authority uncertainty. The research models ex-post case when the Central Bank announces a short increase of the interest rate and conditional commitments to decrease it in the nearest future, which reduces the professional depositors exceptional yield.

Kung (2015) investigated "equilibrium term structure of ... interest rates and the time-varying bond risk premia implied by ... monetary policy shocks". Significant deformation of a term structure and yield followed by monetary policy shocks is really about the investigated Russian case, when some depositors consciously took risks of investing in longerterm deposits and expected higher return from the following economic recovery. But the article is about bond prices and yield, while the Russian case is about household deposits with significant number of behavioral, contractual and regulatory details. The features of bond market determine redistribution of profit and losses between various investors without significant troubles for issuers and bankers. The professional depositors' behavior during monetary policy shocks extracts profit from the banking system and increases system-wide risks covered by the state deposit insurance system.

\section{Prerequisites for Fixers' Raids: The Saving and Flexi Fixed Deposits and Significant Increase in Federal Fund Rate}

An average depositor is not able to forecast economic cycles and monetary policy changes. Even a professional depositor wouldn't risk opening a deposit for several years in an assumed December 2014, even though a rate is 2-3 times higher than the pre-crisis level. There is a possibility of repetition of the 1998-2000 scenario, not the 2008-2011 scenario, with continuing devaluation of the ruble after a crisis peak and retention of high interest rates over several years. Specific features of deposit contracts and that clever use could minimize the risk of rates increase above the endof-2014 level.

Simply stated, there are three types of deposits offered by commercial banks in Russia: (1) a classical deposit for a certain time period without partial money depositing or withdrawal, (2) a saving deposit allows depositing additional money in any time of the contract, (3) a flexi fixed deposit as the combination of classical deposit and demand deposit. The last one allows money depositing and withdrawal in any time of the contractual period without losing the interest, but no less than required minimal balance (from 3 to 30 thousand rubles depending on a bank - from 0.1 to 1 k.\$). Apparently these three types of deposits give banks various liquidity risks, and banks offer lower rates on every option of deposits flexibility.

Often banks noticeably undercut rates of flexi fixed deposits thus making them unattractive for professional depositors, at the same time they leave a small interest spread between classical and saving deposits. In that case the depositors open a sequence of deposit contracts with different maturity, for example, for 6, 12, 18 and 24 months, deposit minimum balances into every one and the main sum - into the shortest contract. Then if the strategy proves successful, and market interest rate decline, the main sum is deposited into the next (longer) contract. If the strategy fails, and rates begin to grow, the professional depositors undertake higher interest on minimum balances only.

According to the legislation a bank can't change deposit terms and conditions at its own discretion even if market interest rate change significantly. Sometimes interest rates can be variable, or there is a stipulation about interest rate 
revision if the federal fund rate changes, but such terms are not widespread. In 2009-2011, when interest rates fell significantly, some private banks tried to impose fees for additional money depositing on saving contracts signed during the crisis. Professional depositors successfully filed complaints in CBR and won legal cases, so that any changes in existing deposit contracts were prohibited. Private banks had to follow the initial deposit terms and pay high interest rates to fixers.

Facing growth of political and economic concern at the beginning of 2014, professional depositors preferred flexi fixed deposits more. Market interest rates were relatively low, an interest spread between classical and flexi fixed deposits was about 2 percentage points. Moreover, flexi fixed deposits in big reputable private banks were at the level of Sberbank fixed deposits. Professional depositors estimated the risk of significant changes of macroeconomic indicators significantly higher than $2 \%$ for deposit flexibility. Some professional depositors preferred the sequence of short term classical deposits for no longer than 3 months each.

During spring-summer of 2014 interest rates were growing steadily by 1 percentage point over several months. In December 2014 CBR significantly increased the federal fund rate from $11,5 \%$ to $17 \%$ at one time. After CBR decision, several large private banks raised interest rates on deposits from $10-12 \%$ to $19-21 \%$, some small risky banks raised the rate up to $23-25 \%$. Such banks drew depositors from conservative banks, that didn't want to take high interest rate risks, and finally even conservative banks had to raise their interest rates.

So, according to the monitoring by the Central Bank of Russia, maximum interest rates (on ruble deposits) of ten commercial banks with the largest share of private depositors raised from 10,58\% in the first decade of December 2014 to $15,31 \%$ in the second decade of the month [rus5].

Probably CBR and the largest commercial banks planned to use such an expensive way of preventing currency panic for a very short period of time. Then, in the following spring or summer the interest rate were planned to return back to the pre-crisis smaller level, just as it was done in 2009. Increasing rates for 3-6 months deposits only by the majority of banks confirm the conventional expectations. Those large banks that doubled the interest rates for 1-2-year deposits came to senses in few weeks and left the increased rates only on short-term deposits.

In the context of a 1-2\% increase of interest rates depositors preferred to wait till the existing deposits expiry date and only then transfer money to new deposits with higher rates. Doubled interest rates in December 2014 made the strategy of losing 2 month interest more profitable than waiting for the deposit expiry date. Arithmetic rate of $20 \%$ per annum means that a month rate is $1.6 \%$, and $8 \%$ per annum $-0.6 \%$ p.c.m. Thus, 45 days of incremented rates of a new deposit outweigh loss of 2-months interest on old low interest deposits. Depositors with flexi fixed contracts didn't lose any accrued interest at all when withdrawing the bulk sum from the deposits to the minimum balance. Previously they have been losing $2 \%$ yield, and that high liquidity costs pays back in two months on a new deposit with high rates.

Many private commercial banks saw long queues of professional depositors, people checked in in the morning to have an opportunity to accomplish transactions with deposits in the evening. From the side it looked like depositors were running away, Mass Media had no idea of what was happening, contributing panic plotting to that impression. In that December reality few depositors form the queues drew money to buy currency or foreign cars, as those small groups who didn't believe in rubles and drew money out in October-November. More than half of the queues were professional depositors who wanted to reopen or to "fix" deposits with the new doubled interest rates. Other significant group of the depositors transferred money out of banks that didn't hurry to review interest rates to the banks that quickly did it. So, vast majority of the queue believed in the repetition of the 2009-2012 scenario with recovery of the ruble and economy, in possibility to get outstandingly high yield.

\section{Quantifying the Fixers' Actions and Private Banks Losses}

CBR doesn't disclosure direct statistics of deposits by those types (classic, saving or flexi fixed) and early withdrawal. And there are no direct statistic figures about professional depositors as relatively new and under researched phenomenon. Indirectly the share of professional depositors could be calculated based on statistical evidences of main the depositors' strategies, such as splitting deposits around the sum of maximum deposit insurance coverage or depositing a fraction of money into hard currency deposits. The last strategy is not the case for this research, but empirically possible reference (briefly pointing professional depositors try to predict significant changes in ruble/ dollar/ euro exchange rate changes).

So, DIA annual survey of household deposits specifies the deposits by size and points that deposits around the maximum insurance coverage was 23\% (in 2013) [rus10]. CBR disclosure the share of hard currency deposits about 22\% [rus6], with significantly higher share in Moscow, the Moscow region and Saint-Petersburg (34\%) and the rest of the country (11\%). Again, the research is about crisis behavior of ruble denominated household deposits, but the two figures 
are nearly equal and correctly reflect the size of professional depositors' phenomena.

Estimation of the professional depositor phenomenon can probably be based on the population age structure and an assumption that senior citizens have more confidence in state owned banks, and the younger generation - trusts private banks more. But practical observations prove otherwise - queues with a lot of senior citizens in large private banks and even in some risky banks. At least some of them help their younger relatives to split deposits not to exceed the DIA insurance coverage. Besides, many seniors consciously choose more profitable deposits insured by the DIA as a government agent.

Observations show that fixers are more numerous in Moscow, the Moscow region and Saint-Petersburg. The private banks overplay state owned banks in the three regions by the share of branches $57 \%$, but state owned banks significantly dominate in the rest of the country with $74 \%$ of branches. When public were seeing the depositors raids in Moscow during crisis-high interest rates, there were almost no queues of depositors in the rest of the country. In thematic social nets forums (such as www.banki.ru) out of 10 participants 6 were from Moscow, 2 - from the Moscow region, 1 from Saint-Petersburg and 1 - from other regions.

Many managers of private banks point the huge proportion of professional depositors through the banks customers. For example, Natalia Blatova, Deputy Chairman of the Board of MDM Bank (one of the oldest and largest private banks) said to the daily business media Kommersant: "The situation in Moscow is slightly different from regional. They are mainly professional depositors that open deposits up to 700 thousand rubles, the sum insured by the DIA" [rus8]

CBR statistics shows that three main regions of professional depositors activity contributes $49 \%$ to total the country household deposits. Excluding five the biggest commercial banks, which are state owned, the rest of Russian deposit market controlled by private banks is $43 \%$ [rus6]. The penetration of private banks in there the main regions significantly bigger than in the rest of the country - $57 \%$ and $26 \%$. As the result, according to the facts of the regional concentration of professional depositors, their share is less than $28 \%$ of total the country household deposits. Less than $28 \%$ means not all depositors of private banks in three main regions are professional ones, but vast majority.

As calculated earlier $8.8 \%$ of all household deposits expire every month followed by statistical term structure [rus4], and $54 \%$ of that value are long-term deposits. Vast majority of those money operated by ordinary depositors, which contracts lucky expired in the period of crisis-high interest rates or a month before. Ordinary depositors could not forecast macro indicators and do not use complicated saving strategies, but obviously reopen deposits with crisis-high interest rate too.

Again, the share of deposits around the ceiling of DIA coverage is $23 \%$, the share of hard currency deposits is $22 \%$ and the share of private banks in the tree main Russian regions is $28 \%$. When three figures are closer to each other and there are no obvious preferences, the best choice is arithmetic average $24 \%$, which is finally understood as the share of professional depositors in the whole household deposits. Plus the ordinary depositors impact $\left(26 \%{ }^{*} .54 * .76=10.8 \%\right)$, and totally $35 \%$ of household deposits would be a headache for private banks over 2015-16. Or, rather, banks will realize significant interest rate risks on those $35 \%$ of deposits.

In theory, banks shift the burden of increased deposit rates onto credit users, and business, in its turn, gets additional income on the ruble devaluation and increased inflation. Then economy recovers, inflation slows down and deposit and credit rates return to lower levels with no negative effect on banks income and stability. But in reality banks are not always able to change coincidently their assets and passives rates, realize interest rate risk, and get losses and toxic assets.

Formally the overwhelming majority of credit contracts contain a stipulation that a bank can raise the interest rate at its own discretion after the change of the federal fund rate. In the real world banks constrainedly delay increase of credit interest rates or quickly cut credit rates after the Central Bank of Russia, competing for good borrowers. Bad borrowers would hardly go to competitor banks, they would rather accept increased rates and delay rates decrease, but would pay at the cost of compound debt and its future writing-off.

As it was indicated earlier, professional depositors re-opened significant number of deposits in several weeks, and banks will have to pay high rates during the following 1-2 years incapable of reconsidering deposit terms. Bank margin will show very small average and even negative figures on some banks and types of deposits. In evidence of that CBR data should be given here concerning deposit and credit rates of the previous economic cycle that can recur after the end of December 2014 crisis.

So, in the previous economic cycle, after the crisis peak of autumn 2008 - winter 2009 , federal fund rate began to go down in February 2009. Deposit rates demonstrated statistical decrease just in October, in other words with an 8month delay. Apparently, banks offered decreased rates in spring 2009, but for many months they had to repay their previous crisis-high obligations. After 8 months the interest rate risks realization, average bank margin fell down from $5.9 \%$ in January'09 to $1.5 \%$ in October'09. 
(The chart and calculations refer to credit versus deposit rates without demand deposits and deposits less than one month. Hard currency deposits were left out as well for their share is relatively small, and rates are more stable).

Diagram: "Fluctuations of interest rates on credits and deposits and bank margin during the financial crisis of 2008 and following recovery" [rus9].

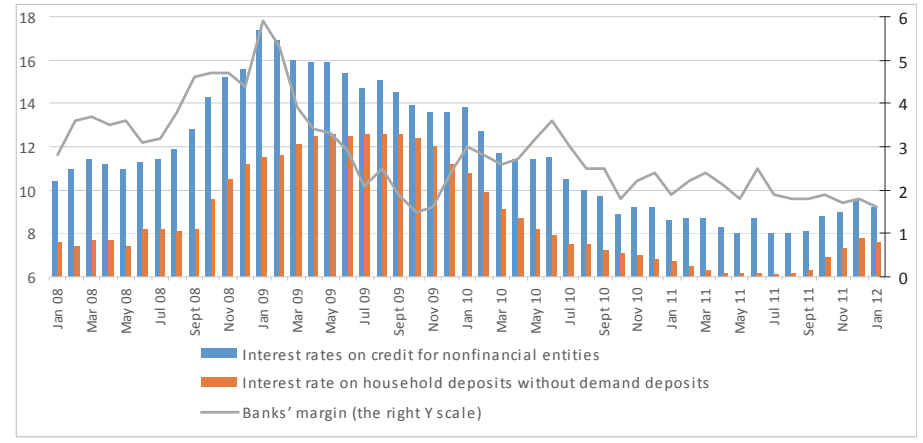

Thus, the refinancing rate was $10 \%$ in January'08 and reached its maximum of $13 \%$ in January'09. Within the same period interest rates on deposits grew from $7.6 \%$ to $11.6 \%$, which is more than by half. $3 / 4$ out of 4 percentage points of the rates increase ended up in the bank margin decrease at the end of 2009.

It must be emphasized again, that the diagram is based on the Central Bank statistics, like "comparing apples to oranges". Sberbank and other state owned banks, less attractive for professional depositors and with a big passive base on demand deposits, worked with a positive margin. Whereas many private banks, heavily dependent on professional depositors, showed loses in 2009 financial statements.

Much more problems are forecasted for private banks in 2015, compared to 2009. Activity of professional depositors and especially fixers increased many times, the federal fund rate was raised much more, and conventionally will decrease by as much. So, in the second half of 2014 the rate grew from $8.5 \%$ to $17 \%$ (by 8.5\%), the bank margin in October' 14 was $4.5 \%$ at the average. Judging by the 2009 situation when the $3 / 4$ of the rate change ended up in the bank margin, the margin in the end of 2015 can be expected at minus 1.5 percentage points.

\section{Preventing Further Spread of Professional Depositors by Suggested Legal and Supervisory Restrictions and Increasing Practice of Conditional Commitments of the Monetary Authority}

CBR and legislative bodies should think about ways of limiting fixers' activity for future use. The current crisis pointed at a more significant growth of the base rate compared to 2008-2009 and increased fixers raids. The next crisis (it will definitely happen due to the cyclicality of economy) will make the interest fixation massive.

To prohibit fixation completely, saving and flexi fixed deposits should be eliminated, which is impossible. Explicit ban on such deposits similar to prohibition of early deposit withdrawal will lead to reduction of terms of classic deposits and massive use of deposit sequences. Banks would simply lose long-term funds, and depositors will early withdraw existing deposits in a crisis losing of 1-2 months interest accrued.

Adjustment of interest rate depending on a deposit terms should be acknowledged as a more effective way. CBR successfully restricts the sealing of interest rates for risky banks based on the average rate of the ten largest banks plus several percentage points. In a similar way CBR should define the minimum reduction percentage points for each option of deposit flexibility. In other words, smooth the gap between demand (with tokenistic interest rates) and classic deposits.

For example, in pre crisis June 2014 a classic deposit 1-year long was offered by a typical large private bank with $12 \%$ per annum, a saving deposit $-10 \%$ and a flexi fixed deposit - $9 \%$. So the gap between a demand and flexi fixed deposits (actually a sum above the minimum balance is a demand deposit) was 8-9 percentage points. The gap between a flexi fixed and a classic deposit was many times less, and this gap should be adjusted to make depositors bear bigger costs for each flexibility option.

From the point of view of the system wide stability the following percentage structure should be considered as more correct. Let's say, a classic deposit gives $12 \%$ and a demand deposit gives $0,5 \%$, then a flexi fixed deposit should bring $4 \%$ and a saving one $-8 \%$. That interest rate gap can be defined as a ratio of $1 / 3$ and $2 / 3$ of classic deposit interest 
rate or as a decreased of a certain number of percentage points. That adjustment can be set forth in the same document where the maximum limit of deposit rates is stipulated based on the offers of ten largest depositary banks.

Fixers' raids were largely provoked, as it was shown above, by an unusually high increase in the federal fund rate. During the crisis of 2008-2009 the increase of the rate was less, and activity of fixers was less as well. It is easy to advise CBR to avoid controversial decisions during currency crisis and depositors' panic, but apparently it is much harder to make important decisions in such complex environments.

The US Federal Reserve combines traditional interest-rate policy with verbal interventions, stipulating the limits of rates increase (conditional commitments and unconventional monetary policy tools). It should be briefly reminded that the US Fed very clearly states that low rates will last until a certain level of unemployment and inflation, only then rates will definitely be raised.

Translating that idea into Russian reality of 2014 CBR should announce timelines and economic indicators of the federal fund rate increase. For example, the rate increases only for 3-4 months to stop currency panic and an inflationary shock. The period of high rate can be confirmed with a reference to more complex methods of inflation targeting.

Offering verbal interventions of temporal the rate increase are supported by the standpoint of the RF Ministry of Finance, Ministry of Economic Development and business communities. Two important ministers advised CBR not to delay decrease of the rate in 2015 and energetically promoted additional solutions to cope with depositors' panic and the inflationary shock. The business community unanimously spoke against such a significant increase of the rate, assuming that it would deepen economic downturn.

Let's suppose that CBR in its motivation to raise the rate defined the timelines and economic indicators for its following decrease. For example, it stated that it would start to decrease the base rate within 3-6 months, if outflow of ruble deposits stops and inflationary peak gone out. Then commercial banks wouldn't offer high rates to long-term deposits, they would do it to a short-term ones only. That's what commercial banks finally did, but only after the month of fixers' raids, when they open big number of long-term deposits with high rates.

The last suggestion is to constrain significant increase of commercial banks' interest rates on long-term deposits beyond the announced commitments of the Central Bank of Russia. And either CBR can limit the interest rates growth, or commercial banks will have to follow its commitments in terms of timelines of the rate increase. That suggestion is a combination of the two abovementioned and it can also be stipulated in the same document, defining the maximum interest rate on the basis of the average of the ten largest banks.

For example, CBR in its press-release announces an increase of the federal fund rate in the rationale, saying that the rate will remain high for 3-6 months. Definition of the time period for the high interest rate is binding for commercial banks in increase of their deposit interest rates. If devaluation continues and inflation is high after 3-6 months, CBR repeats its decision with new time-limits and economic indicators of high rates, and commercial banks continue to keep high rates on short-term deposits. In case of stable exchange rate and a downward inflation, CBR follows its initial plan to decrease the federal fund rate, and commercial banks don't take significant interest risks.

So many pros and cons of offered interest rate regulation could be mentioned by the supporters of liberal economic doctrine or supporters of state interventions. The offering interest rate regulation really constrains private initiative and business of private commercial banks. There is no a hundred percent guarantee the directors of Central banks provide sustainable and timely correct monetary policy actions. But the number of bank scandals and bankruptcies in Russia and even in the US and the UK, massive bailouts of "too-big-to-fail" provide clear evidences that interest rate risks should be framed more than existing regulation. The offering regulation is not for professional speculators and derivative contracts; it is for day-to-day retail banking when public expects stability first. Central bank of Russia strictly regulate (and many other Central banks do the same) insured retail deposits and their maximum interest rates. And there is no significant additional constrain of retail banking if the banks will follow the regulator's guideline of the longevity of interest rate changes and various options of the deposits' flexibility. Again the offering solution is simply incorporated into existing regulation of ensured retail deposits without its significant expansion, and expected to bring more stability and constrain losses of so many banks.

\section{Conclusion}

Professional depositors use forced tolerations and sometimes even mistakes of commercial banks and monetary policy makers to get bigger yield. As well as professional buyers dissipate retailers margin by using various special offers, coupons and discounts more often than ordinary people do. Mainly professional depositors are associated with the moral hazard of deposit insurance, and in the crisis of 2008 and 2014 they fixed crisis-high interest rates beyond the crisis peak for several years. 
They do that expecting quick return of crisis-high interest rates to pre-crisis low figures after the relief of panic and beginning of economic recovery. According to the legislation, commercial banks are not allowed to change the terms of existing deposit contracts, even in cases of significant decrease of interest rates and fixers' significant money depositing beyond minimal deposit required. Also household deposits are insured by Deposit Insurance Agency (DIA), which equalizes risks of placing savings in Sberbank (the largest state owned and the least risky bank) and in a small risky private bank.

So, during the crisis-high interest rates, professional depositors' contract flexi fixed deposits in various private banks with maturity as long as possible. Later when their existing pre-crisis deposits end up, they simply place money to new crisis-high yield deposits, even if market rates decline significantly. In December 2014 CBR raised the federal fund rate from $11,5 \%$ to $17 \%$ to cope with currency crisis and following high inflation. Private banks had to raise interest rates on household deposits from 10-12\% to 20-23\% over all deposit periods, including several years time.

Together with a scheduled monthly renewal of ordinary deposits and high activity of professional depositors in just one month of extremely high rates on long-term deposits up to $30 \%$ of deposits were re-opened or fixed for over 2-3 years. In case of the 2009-2011 scenario repetition with quick stabilization, decrease of inflation and the federal fund rate, banks will have to cut credit rates and continue to pay high deposit rates. Due to that, private banks will bear significant interest risks in 2015-2016 and will work with a negative margin minus $1.5 \%$ on this $1 / 3$ deposits.

Fixers just appeared in 2008 and in December 2014 the phenomenon was so wide-scale, that there were long queues of depositors that looked like reversed panic. So, it is important for legislation and monetary policy makers to cope with future negative implications of fixers' actions. First of all, saving and flexi fixed deposits should bring $2 / 3$ and $1 / 3$ percentage points of the gap between classical and demand deposits, that are significantly less than now. Secondly, CBR should use conditional commitments more and inform public of time limits of the high rate and announce indicatorstriggers for its quick decrease. Thirdly, commercial banks must follow the regulator's time frames to raise their interest rates only for short term deposits.

The second and the third suggestions can be implemented in the existing regulation of maximum deposit rates based on rates of the ten largest banks. It should be reminded that if a bank exceeds the interest rate ceiling on saving or flexi fixed deposits, as well as announced time frames for new crisis-high yield deposits, CBR quickly bans new deposit contracts of the bank. Analogy of the second suggestion is the US Fed practice of verbal interventions that are called «conditional commitments as unconventional monetary policy tools» in professional literature.

Note: The case had been researched and the article written over December 2014 and January and February 2015, when there was the deepest time of financial turbulence in Russia. The exchange rate of Russian Ruble fell from 35 to 72 Rubles per USD (February peak), the federal fund rate jumped from 12 to 17\% (December peak) and conventional meaning was over pessimistic. In that time there was very brave to predict quick macroeconomic stabilization, ruble appreciation and fall in interest rates - as tens of thousands if professional depositors hoped and conformed their opinions by small minimal deposits balances only. Later in March-May of 2015, when the article processed through the journal editing and revising, macroeconomic situation in Russia improved as expected by the professional depositors. Russian ruble appreciated from 72 to 49 rubles per 1 dollar and the federal fund rate fell from 17 to $12.5 \%$, commercial banks stopped offering high yield deposits. Many professional depositors have made true stakes and created significant losses for some big retail banks, which started materializing in financial statements over the period ended in 31.03.2015.

\section{References}

Bartholdya et al., 2003. Jan Bartholdya, Glenn W. Boyleb, Roger D. Stover Deposit insurance and the risk premium in bank deposit rates Journal of Banking \& Finance. Volume 27, Issue 4, April 2003, Pages 699-717.

Anginera et al., 2014. Deniz Anginera, Asli Demirguc-Kuntb, Min Zhuc, 1, How does deposit insurance affect bank risk? Evidence from the recent crisis.

Journal of Banking \& Finance. Volume 48, November 2014, Pages 312-321.

Gueyie1 and Laib, 2003. Jean-Pierre Gueyie1, Van Son Laib, Bank moral hazard and the introduction of official deposit insurance in Canada.

International Review of Economics \& Finance. Volume 12, Issue 2, 2003, Pages 247-273.

Yanga et al., 2014. Hsin-Feng Yanga, Chih-Liang Liub, Ray Yeutien Choua, Interest rate risk propagation: Evidence from the credit crunch.

The North American Journal of Economics and Finance. Volume 28, April 2014, Pages 242-264.

Smitha and Egterenb, 2005. R. Todd Smitha, Henry van Egterenb Interest rate smoothing and financial stability

Review of Financial Economics. Volume 14, Issue 2, 2005, Pages 147-171.

Gimeno and Marqués, 2012. Ricardo Gimeno, José Manuel Marqués A market based approach to inflation expectations, risk premia and 
real interest rates.

The Spanish Review of Financial Economics. Volume 10, Issue 1, January-June 2012, Pages 18-29.

Giorgioa and Rotondi, 2011. Giorgio Di Giorgioa, Zeno Rotondi Financial stability, interest-rate smoothing and equilibrium determinacy. Journal of Financial Stability. Volume 7, Issue 1, January 2011, Pages 1-9.

Hasana et al., 2013. Iftekhar Hasana, Krzysztof Jackowiczb, Oskar Kowalewskib, Łukasz Kozłowskie Market discipline during crisis: Evidence from bank depositors in transition countries

Journal of Banking \& Finance. Volume 37, Issue 12, December 2013, Pages 5436-5451.

Maechler1 and McDill, 2006. Andrea M. Maechler1, Kathleen M. McDill Dynamic depositor discipline in US banks. Journal of Banking \& Finance. Volume 30, Issue 7, July 2006, Pages 1871-1898.

Special Section: Banking and Finance in an Integrating Europe

Schluetera et al., 2015. Tobias Schluetera, Soenke Sieversb, Thomas Hartmann-Wendelsa Bank funding stability, pricing strategies and the guidance of depositors.

Journal of Banking \& Finance. Volume 51, February 2015, Pages 43-61.

Zulkhibri, 2012. Muhamed Zulkhibri Policy rate pass-through and the adjustment of retail interest rates: Empirical evidence from Malaysian financial institutions. Journal of Asian Economics. Volume 23, Issue 4, August 2012, Pages 409-422.

Wanga and Leeb, 2009. Kuan-Min Wanga, Yuan-Ming Leeb Market volatility and retail interest rate pass-through. Economic Modelling. Volume 26, Issue 6, November 2009, Pages 1270-1282.

Chernykha and Coleb, 2011. Lucy Chernykha, Rebel A. Coleb, Does deposit insurance improve financial intermediation? Evidence from the Russian experiment

Journal of Banking \& Finance. Volume 35, Issue 2, February 2011, Pages 388-402.

Fungáčová1 et al., 2010. Zuzana Fungáčová1, Laura Solanko, Laurent Weill. Market power in the Russian banking industry International Economics. Volume 124, April 2010, Pages 127-145

Papadamoua et al., 2014. Stephanos Papadamoua, Moïse Sidiropoulosb, Eleftherios Spyromitrosb.

Central bank transparency and the interest rate channel: Evidence from emerging economies Economic Modelling. Available online 31 October 2014.

Klappera et al., 2013. Leora Klappera, Annamaria Lusardib, Georgios A. Panosc, Financial literacy and its consequences: Evidence from Russia during the financial crisis.

Journal of Banking \& Finance. Volume 37, Issue 10, October 2013, Pages 3904-3923.

Jonesa and Kulishb, 2013. Callum Jonesa, Mariano Kulishb

Long-term interest rates, risk premia and unconventional monetary policy. Journal of Economic Dynamics and Control. Volume 37 , Issue 12, December 2013, Pages 2547-2561. Kung, 2015. Howard Kung

Macroeconomic linkages between monetary policy and the term structure of interest rates. Journal of Financial Economics. Volume 115 , Issue 1, January 2015, Pages 42-57.

\section{References to Russian Statistic Sources and Opinions}

Бурыкина Н.В., Председатель комитета по финансовому рынку Государственной Думы РФ, Интервью // banki.ru - 25.11 .2013$. http://bosfera.ru/news/protiv-professionalnyh-vkladchikov\#).

Исаев Ю.О., Руководитель Агентства Страхования вкладов Интервью // Коммерсанть - 23.12.2013. (, https://www.asv.org.ru/ agency/publication/309087/)

Банк России/ Статистика/ Инструменты денежно-кредитной политики Банка России и показатели ликвидности банковского сектора/

http://cbr.ru/print.asp?file=/statistics/credit_statistics/refinancing_rates.htm\&pid=idkp_br\&sid=ref

Банк России/ Статистика/Банковский сектор/Показатели деятельности кредитных организаций/ Данные об объемах привлечения кредитными организациями вкладов (депозитов) физических лиц/ 2014 г.

http://cbr.ru/statistics/print.aspx?file=bank_system/4-2-1a_14.htm\&pid=pdko_sub\&sid=dpbvf

Банк России/ Статистика/ Банковский сектор / Показатели деятельности кредитных организаций/ Динамика максимальной процентной ставки ... десяти кредитных организаций ... http://www.cbr.ru/statistics/?Prtid=avgprocstav\&pid=pdko_sub\&sid= ITM_2386

Банк России/ Статистика / Банковский сектор/ Сведения о привлеченных и размещенных средствах/ Привлеченные средства/ Сведения - средствах организаций, банковских депозитах .... на 1.11.14, http://cbr.ru/statistics/?Prtld=sors, http://cbr.ru/ statistics/UDStat.aspx?Month=11\&Year=2014\&Tb/ID=302-22-G30).

Банки.ру // Форум / Вклады / Спец.тема для оголодавших фиксаторов. http://www.banki.ru/forum/?PAGE_NAME=read\&FID= $12 \& T I D=264568$

Блатова Н.А., заместитель председателя правления МДМ Банка, Интервью // Коммерсантъ, 6.10.2014. (http://www.mdm.ru/ almetevsk/press/publications/2014-10/3754/)

Банк России/ Статистика/ Банковский сектор/ Процентные ставки/ Ретроспективный блок/ Ставки по кредитам нефинансовым организациям и депозитам физических лиц в российских рублях/ 2008-12 гг. http://cbr.ru/statistics/?Prtld=procstavnew http://cbr.ru/statistics/print.aspx?file=b_sector/credits_deposits_12.htm\&pid=procstavnew\&sid=itm_48233

ACB, Обзор рынка вкладов физических лиц за I полугодие 2013 года, рис.16 Структура депозитов в зависимости от размера вкладов, стр.17. http://www.asv.org.ru/upload/iblock/c85/mkycx\%20cdyzh\%20cadcvpj_2013___smdgrhtxz.pdf

Банк России/ Статистика/ Банковский сектор/ Показатели деятельности кредитных организаций / Отдельные показатели деятельности кредитных организаций, сгруппированных по величине активов., на 1.11.14. http://cbr.ru/statistics/print.aspx? file=bank_system/4-1011114.htm\&pid=pdko_sub\&sid=opdkovo 